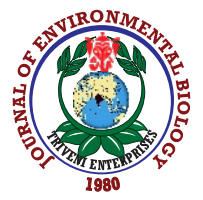

\title{
Redescription of Rhabdochona baylisi Rai, 1969 from a cat fish, Eutropiichthys vacha from Jiri River, Jiribam, Manipur, India
}

\author{
C.D. Devi, R.K.S. Singh* and R.K. Gambhir \\ Parasitology Section, Centre of Advanced Studies in Life Sciences, Manipur University, Imphal-795 003, India \\ *Corresponding Author Email : chrkjiri@gmail.com
}

\section{Abstract}

Aim: To investigate and record a taxonomic account on parasite fauna of freshwater fishes from Jiri River, Jiribam, Manipur (India).

Methodology: During the taxonomic study carried out in January-April 2019, the fishes were collected, anaesthetised, and examined for the presence of parasites. Recovered parasites (two gravid female and four adult male and one juvenile nematode species) from the intestine of Eutropiichthys vacha were washed, fixed, and dehydrated in Glycerine Alcohol. The permanent slide specimens were examined under a light binocular microscope.

Results: Based on the study, the recovered nematode was identified as Rhabdochona baylisi Rai, 1969 of the genus Rhabdochona Railliet, 1916.

The identified species possessed 8 prostomal teeth, U-loop shape vagina, smooth eggs, and tail with a rounded tip in both sexes. Thus, it can be assigned to the subgenus Globochona Moravec, 1972a. Moreover, it resembles with their conspecies $R$. mazeedi, R. garuai, $R$. bosei and $R$. baylisi, in general morphology. Comparing the relative characteristics with their conspecies, the present species has closely resembled Rhabdochona baylisi Rai, 1969 but differs in a few aspects such as the spicule length ratio (1:3.3 vs. 1:5.5), shorter with blunt tip left spicule in present species whereas more longer with bifurcated distal tip in $R$. baylisi, the number and arrangement of caudal papillae $(13+0+5 \mathrm{vs} .12+0+4)$, The present species posses 8 prostomal teeth whereas teeth are not reported in $R$. baylisi. Inspite of some intraspecific variations the identified specimen shows major resemblance with the $R$. baylisi, thus it was assigned to Rhabdochona baylisi Rai, 1969 as a new redescription record from Jiri River, Jiribam, Manipur (India).

Keywords: Eutropiichthys vacha, Jiri River, Manipur, Nematode, Rhabdochona

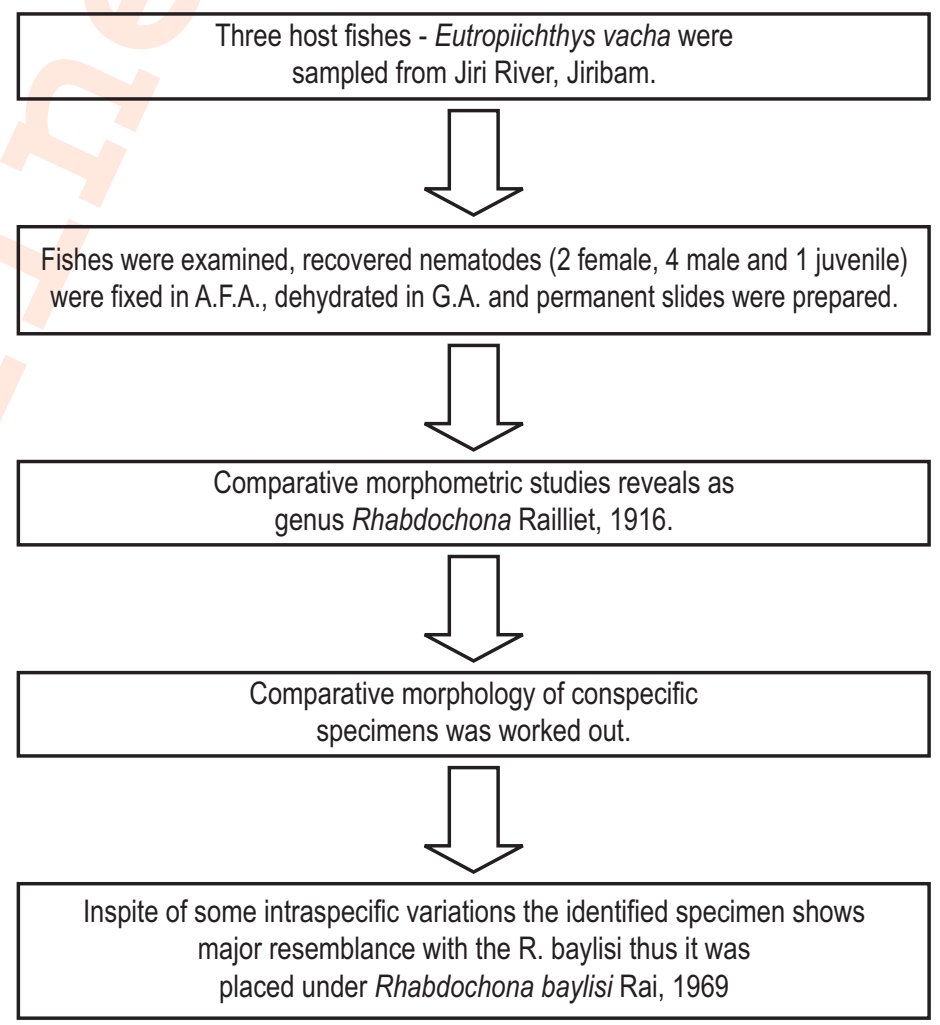

How to cite : Devi, C.D., R.K.S. Singh and R.K. Gambhir: Redescription of Rhabdochona baylisi Rai, 1969 from a cat fish, Eutropiichthys vacha from Jiri River, Jiribam, Manipur, India. J. Environ. Biol., 41, 861-866 (2020). 


\section{Introduction}

North East India is considered as one of the hot spots of freshwater fish biodiversity in the world (Kottelat and Whitten, 1996). Since Manipur is located in the extreme east zone of India, there is a greater chance in the available of fish fauna being influenced by Burmese fish fauna. According to recent reports a total of 139 ornamental fishes are found in Manipur. Out of the total 139 ornamental fishes found in the state of Manipur, 61 were recorded from Jiribam alone (Khomdram et al., 2014).

Besides, a total of 117 fish species belonging to 65 genera and 25 families has been recorded from Chindwind headwaters in Manipur (Vishwanath et al., 1998). Therefore, Manipur has a rich fish fauna which occurs in varied fresh water habitat. Jiribam is located in the westernmost part of Manipur where it borders with the state of Assam. It is drained by Barak River, Jiri River and many small canals. Jiri River meets the Barak River at Jirimukh conflux and hence, becomes the main reason of harboring a large number and variety of fish fauna (Khomdram et al., 2014). Besides, fish also harbour many parasite fauna. The parasite fauna of freshwater fishes of Jiri River, Jiribam, Manipur, India is not yet fully explored. The present study was, therefore, carried out to record and establish a systematic account of the nematode fauna of fresh water fishes of Jiribam.

The nematode genus Rhabdochona Railliet, 1916 (Rhabdohonidae) comprises a large number of species parasitizing freshwater fishes in all zoogeographical regions (Moravec, 2010). The species of the genus Rhabdochona possessed funnel shaped prostom supported by short longitudinal ridges projecting anteriorly as sharp teeth, long and narrow mesostom. The prostomal structure is a defining character of the genus Rhabdochona (Caspeta-Mandujano et al., 2001; Moravec et al., 2001).

There are records of 97 valid species of the genus Rhabdochona (Moravec and Kamchoo, 2012). Although, taxonomic characters of some Rhabdochona species still remain inadequately described. Therefore new redescriptions are highly needed. Some morphological features that were not observed in R. baylisi Rai, 1969 which was reported from Eutropiichthys vacha (Hamilton, 1822) and Clupisoma garua (Hamilton, 1822) are redescribed in the present study.

\section{Materials and Methods}

Fishes were collected from Jiri River, Jiribam, during January-April 2019. Three fishes, Eutropiichthys vacha (Hamilton, 1822) were anaesthetised and examined for the presence of parasites. The recovered parasites were washed in normal saline solution $(0.7 \%)$. The specimens were fixed in Alcohol Formalin Acetate and dehydrated (Seinhorst's, 1959 rapid glycerine method) in Glycerine Alcohol. The prepared permanent slides were examined under a light binocular microscope, and photomicrographs were taken by Stereozoommicroscope. Diagrams were drawn with the help of Camera Lucida and measurement of holotype and paratype specimens were taken by using ocular micrometer.

\section{Description:}

Rhabdochona (Globochona) baylisi : Body medium sized, slender with finely striated cuticle. Prostom funnel shaped with 8 forwardly directed anterior teeth (Fig. 1B, 1C). Mouth hexagonal surrounded with 2 pairs of cephalic papillae. Simple and small deirids (Fig.1B), vestibule narrow, muscular, extending posteriorly upto the anterior end of oesophagus. Oesophagus long, tail conical.

Female: Body 33.13-37.82 X0.36-0.39 mm, Prostom $0.04 \times 0.02$ $\mathrm{mm}$, vestibule with prostom measuring 0.18-0.19 $\times 0.14 \mathrm{~mm}$. Muscular oesophagus $0.59-0.68 \times 0.04-0.05 \mathrm{~mm}$, glandular oesophagus $4.71-5.96 \times 0.13-0.16 \mathrm{~mm}$. Total length of oesophagus $5.3-6.65 \mathrm{~mm}$. Length of both oesophagus in 1:9 ratio. Nerve ring and excretory pore at 0.27-0.28 mm, 0.42-0.44 $\mathrm{mm}$ respectively from the anterior end. Vulva at $18.76-21.72 \mathrm{~mm}$ i.e., $57.45 \%$ of the body length. Vagina $0.84-0.89 \times 0.11-0.13 \mathrm{~mm}$, post-equatorial, directed first anteriorly and then posteriorly from vulva displaying as inverted U-shape (Fig. 1E, 2E). Embryonated, non filamented, thin and smooth eggs $0.02-0.03 \times 0.01-0.02 \mathrm{~mm}$ (Fig. 1G, 2F). Tail 0.24-0.28 X0.07 mm, conical with a rounded tip.

Male: Body 17.86-20.57 X 0.16-0.21 mm, Prostom 0.03-0.04 x $0.02 \mathrm{~mm}$, vestibule with prostom $0.16-0.17 \mathrm{~mm}$, nerve ring, excretory pore, deirids at $0.23-0.26 \mathrm{~mm}, 0.37 \mathrm{~mm}$ and $0.09 \mathrm{~mm}$, respectively from the anterior end. Muscular oesophagus 0.54 $0.64 \times 0.03 \mathrm{~mm}$, Glandular oesophagus 2.48-4.17 x $0.07 \mathrm{~mm}$, in $1: 8$ ratio, total length of oesophagus $3.13-4.7 \mathrm{~mm}$, representing $22.89 \%$ of the body. Papillae $12+1+4+1$ in pairs, representing 12 pairs of sub-ventral preanal with 1 lateral pair, and 4 pairs of subventral post-anal with 1 lateral pair (Fig.1F). Spicules unequal, non alate, short spicule $0.27-0.36 \mathrm{~mm}$, long one $0.90-0.97 \mathrm{~mm}$, length of spicules in 1:3.3 ratio. Tail conical $0.3 \times 0.07 \mathrm{~mm}$, ending with rounded tip.

$4^{\text {th }}$ stage larva: Body $8.85 \mathrm{~mm}, 6$ teeth, funnel shaped prostom $0.02 \times 0.01 \mathrm{~mm}$, vestibule with prostom $0.11 \times 0.007 \mathrm{~mm}$, nerve ring, excretory pore at $0.17 \mathrm{~mm}$ and $0.25 \mathrm{~mm}$, respectively from the anterior end. Muscular oesophagus $0.36 \times 0.02 \mathrm{~mm}$, Glandular oesophagus $1.93 \times 0.06 \mathrm{~mm}$, total length of oesophagus $2.29 \mathrm{~mm}$, representing $25.87 \%$ of the body length. Tail $0.06 \mathrm{~mm}$, conical with a rounded tip.

\section{Taxonomic summary:}

Type host: Eutropiichthys vacha (Hamilton, 1822)

Local name: Laria (Manipuri)

Site of infection: Intestine 
Type locality: Jiri River, Jiribam (249 $79^{\prime}$ North Latitude, $93^{\circ} 94^{\prime}$ East longitude), Manipur ( $23^{\circ} 50^{\prime}$ North to $25^{\circ} 41^{\prime}$ North Latitude, $93^{\circ} 00^{\prime}$ East to $94^{\circ} 45^{\prime}$ East Longitude), India.

Prevalence of infection: prevalence and intensity of infection $33.33 \%(1 / 3)$ and $7(7 / 1)$ parasite per host, respectively.

Deposition of specimen: Holotype and Paratype specimens were deposited to the museum of Department of Zoology, Manipur University.

Ethical approval: All the procedures performed in research studies using fishes were in accordance with the Ethical Standards of the Institutional Animal Ethics Committee of Manipur University (M.U/D.Sc./ETHICS-7/09).

\section{Results and Discussion}

Taxonomic studies taken during January-April 2019, two female, four male and one juvenile nematode species of the genus Rhabdochona Railliet, 1916 were recovered from the intestine of fresh water fish, Eutropiichthys vacha (Hamilton, 1822) from Jiri River, Jiribam, Manipur (India).

Rhabdochonids are frequent parasites of freshwater fishes all over the world. According to Moravec and Kamchoo (2012), 97 species of the genus Rhabdochona are valid. Saidov (1953) subdivided the genus Rhabdochona into two subgenera, Rhabdochona and Filochona based on the egg filament. Moravec (1975) considered that classification based only on egg is not sufficient to divide the genus Rhabdochona into subgenera and emphasized on other characters such as number and arrangements of teeth in the prostom, presence of cervical alae, shape of female tail tip and shape of deirids. L a te $r$ M o r a v e $c$ subdivided the genus into 4 subgenera, Rhabdochona Railliet, 1916; Globochona Moravec, 1972a; Globochonoides Moravec, 1975; Sinonema Moravec, 1975. But later Chabaud (1975) recognised only 3 subgenera, Rhabdochona Railliet, 1916, Globohona Moravec, 1972a and Filochona Saidov, 1953. Chabaud's classification is followed in this study which was widely accepted by many authors.

The subgenus Globochona Moravec, 1972a are the groups of genus Rhabdochona having 8 or 12 anterior teeth, tail tip of the female widely rounded with numerous spins (dim striations), mucronate points or tooth like processes, eggs smooth or with lateral globules or swellings. Only a few species of Rhabdochona (Globochona) are known from fresh water fishes in tropical and subtropical Asia and Africa (Moravec, 1975; Boomker and Petter, 1993; Wang et al., 1994). Most South Asian Rhabdochona species produce eggs that have neither filament nor provide with any surface ornamentation. In India, six species of Globochona have been reported in freshwater fishes (Moravec, 1975, 2010; Boomker and Petter, 1993; Wang et al., 1994; Moravec and Yooyen, 2011; Moravec and Kamchoo, 2012;
Moravec and Jirku, 2014). Morever, R. (G) puntii (David, 2014) is reported from freshwater Indian fishes. So far 7 valid species of this subgenus is reported from freshwater fishes in India.

The present species is reported from Eutropiichthys vacha. Besides several other Globochona species ( $R$. baylisi, $R$. bosei, $R$. mazeedi and $R$. chanawanensis) have been reported from the same host (E. vacha). Moravec (2010) redescribed $R(G)$ mazeedi Prasad and Sahay, 1965 from Garua bachcha (Hamilton, 1822) in Ganges River, West Bengal, India. Moravec (1975) and Soota (1983) considered R. bosei, Sahay, 1966 as a synonym of R. garuai. Moreover, Sahay and Narayan (1971) considered $R$. baylisi as a synonym of $R$. garuai. Later, Moravec suppressed both $R$. baylisi and $R$. bosei under $R$. (G) garuai. Gupta and Masoodi (1982) agreed with Moravec and redescribed R. (G) garuaiAgrawal, 1965 from Wallago attu. The present species posses 8 prostomal teeth (Fig. 1B, 1C, 2A, 2B), egg smooth (Fig.1G, 2F), tail with rounded tip in both sexes (Fig. 1F, $1 \mathrm{H}, 2 \mathrm{D}, 2 \mathrm{G})$. Thus, it can be assigned to the subgenus Globochona (Moravec, 1972a). Furthermore, the present species also showed similar feature with $R$. mazeedi, R. garuai, $R$. bosei and $R$. baylisi like general morphology, presence of 8 teeth, postequatorially located with U-loop shape vagina (Fig.1E, 2E).

Although the morphology of present species is markedly differed from $R$. mazeedi (redescribed by Moravec, 2010) in shape of deirids (simple, small and pointed vs. small bifurcated), length and shape of spicule (longer left spicule with blunt distal tip vs. unusually short left spicule with bifurcated tip), spicule length ratio (1:3.3 vs. 1:1.6), number and arrangement of caudal papillae $(12+1+0+4+1=18$ pairs, representing 12 sub-ventral pairs with 1 lateral preanal pair, 4 subventral pairs with 1 lateral postanal pair vs. $10-11+2+0+4+2$, representing 10-11 pairs sub-ventral preanal papillae, 2 lateral preanal papillae, 4 pairs of sub-ventral and 2 lateral postanal papillae). The present species also differed from $R$. garuai in shape of left spicule tip (non alate vs. alate), absence of caudal alae in both sexes vs. narrow caudal alae extending upto the tip of tail in male. It also differed from $R$. bosei in shape of distal tip of left spicule (non alate vs. bifurcated), shape of tail (tail with rounded tip in both sexes vs. sharply pointed in both sexes), and arrangement of caudal papillae $(13+0+5$ vs. $11+0+4)$. The eggs were thick shelled in R. mazeedi, R. garuai, R. bosei, and $R$. baylisi whereas thin shelled in the present species.

The present species was found closer to R. baylisi Rai, 1969. Despite similarities of the present species with $R$. baylisi, certain differences were also noted like spicules length ratio (1:3.3 vs. 1:5.5), left spicule shorter with a blunt tip in the present species whereas the left spicule was more longer with bifurcated distal tip in $R$. baylisi, the number and arrangement of the caudal papillae $(13+0+5$ vs. $12+0+4)$, a pair of lateral papillae in both preanal and post anal was observed in present species but lateral papillae were not reported in $R$. baylisi, number of prostomal teeth was not reported in $R$. baylisi. Moreover, in the present study, a 


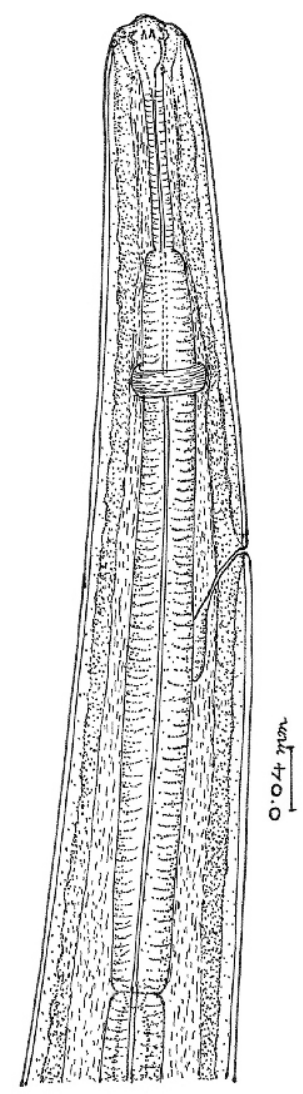

A

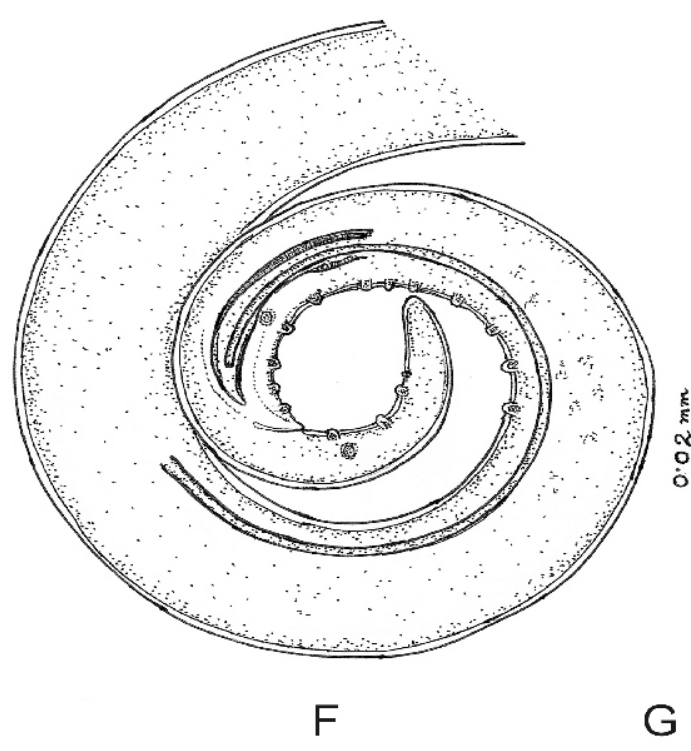

$\mathrm{G}$

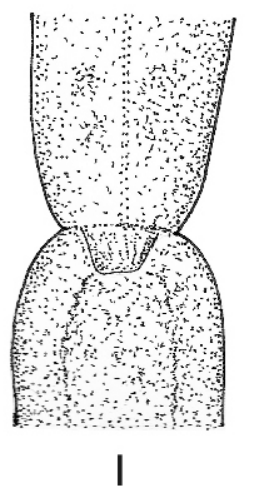

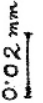
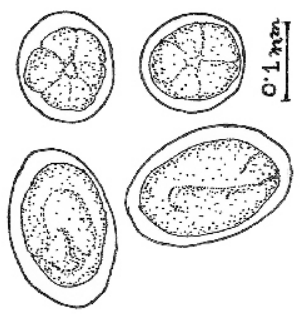

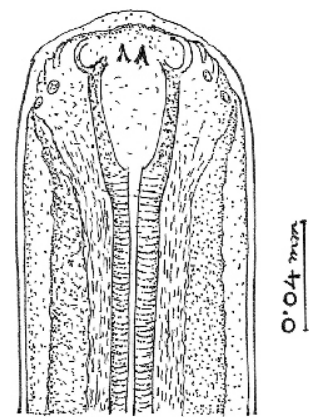

C

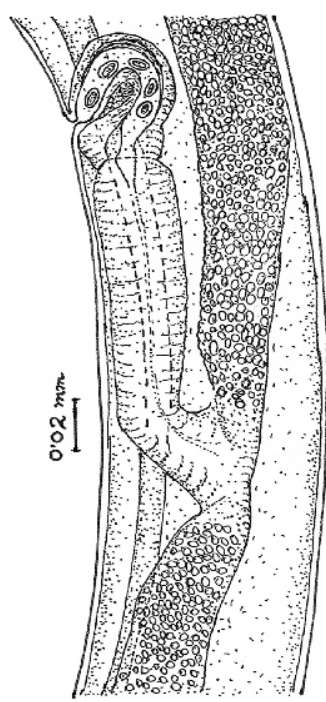

펼
on
음
을

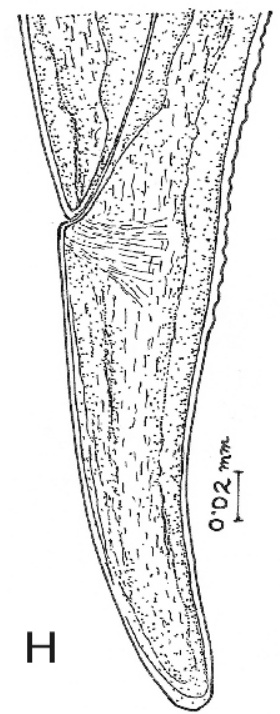

Fig. 1 (A-H): Rhabdochona baylisi. (A) Female anterior end, lateral view (B) Male anterior end, dorsoventral view (c) anterior extremity, enlarge lateral view (D) Vulvar region, lateral view (E) Vagina, enlarge view (F) Male posterior end (G) Embryonated eggs, enlarge view (H) Oesophago-intestinal junction. 


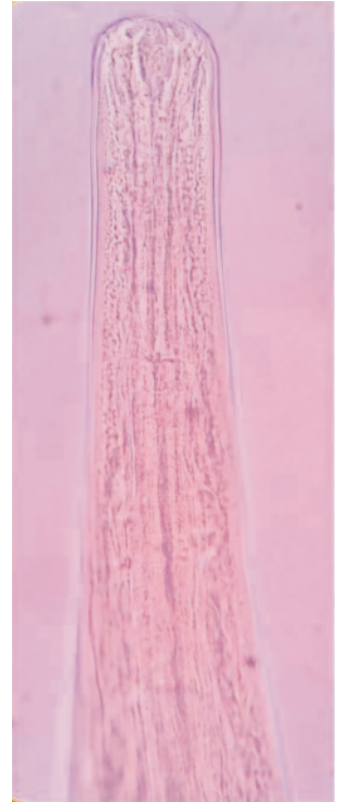

(A)

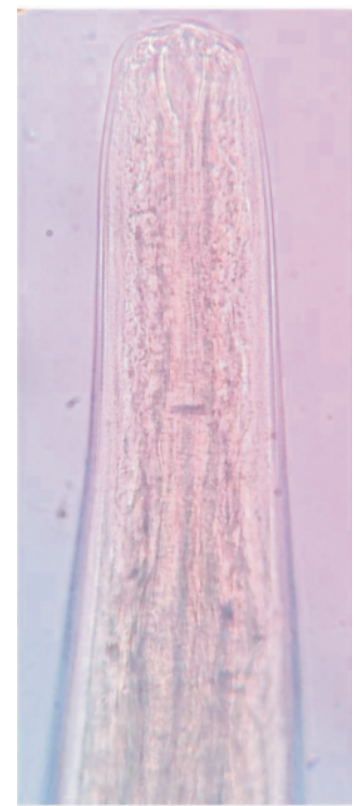

(B)

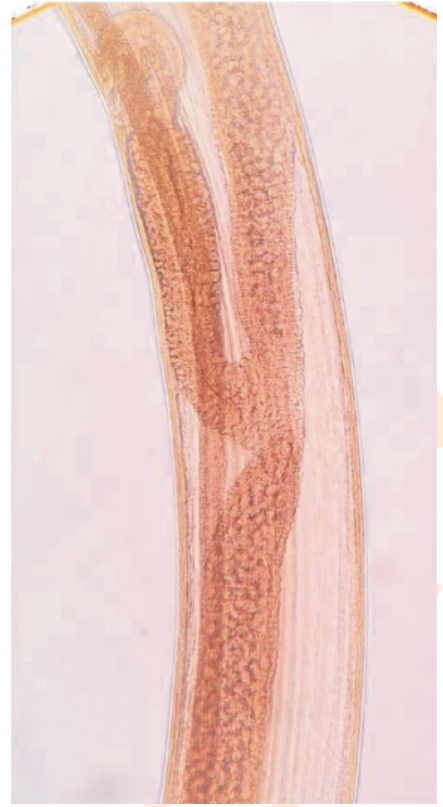

(C)

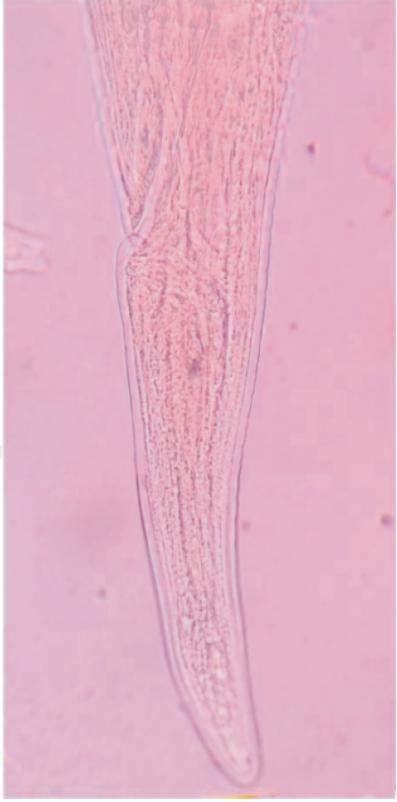

(D)

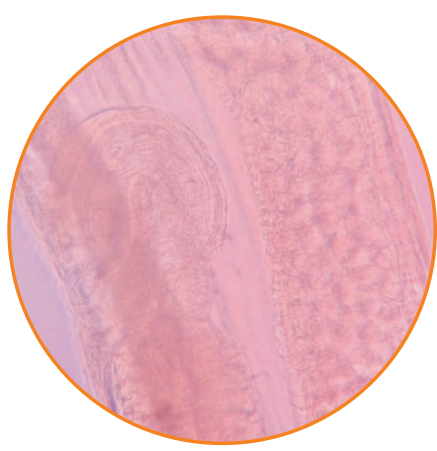

(E)

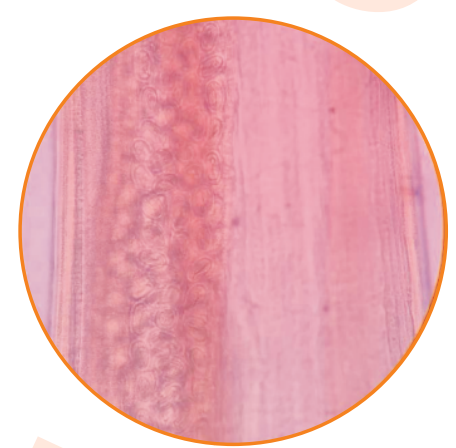

(F)

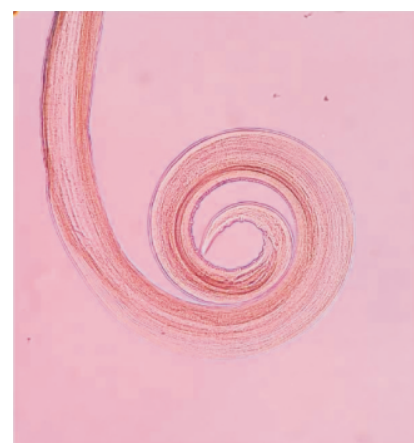

(G)

Fig. 2 : (A-G) Rhabdochona baylisi. (A) Female anterior end, lateral view (B) Male anterior end, dorsoventral view (C) Vulvar region (D) Tail (E) Vagina, enlarge view $(F)$ Eggs $(G)$ Male posterior end.

description of $4^{\text {th }}$ stage larva was reported. Inspite of some morphometric variations the present species shows major resemblance with $R$. baylisi Rai, 1969 in many aspects. The description of the present species has no diagnostic morphological or morphometric differences from $R$. baylisi Rai, 1969 which could allow to erect as a new species. So the present species is assigned to $R$. baylisi Rai, 1969 as a new redescription record from Jiri River, Jiribam, Manipur, India.

\section{Acknowledgments}

The authors are thankful to the Head of Zoology Department, Manipur University, for providing necessary laboratory facilities. We are also grateful to the colleagues and friends for their support during the study.

\section{References}

Agrawal, V.: Some new nematode parasites from freshwater fishes of Lucknow. Indian J. Helminth., 17, 1-17 (1965).

Boomker, J. and A.J. Petter: Parasites of South African freshwater fish. III. Rhabdochona (Rhabdochona) versterae n. sp. (Nematode: Rhabdochonidae) from the spot-tailed robber Alestes imberi Petter, 1852. Onderstepoort J. Vet. Res., 60, 23-27 (1993).

Caseta-Mandujano, J.M., F. Moravec and G. Salgado-Maldonado: Two new species of Rhabdochonids (Nematoda: Rhabdochonidae) from freshwater fishes in Mexico, with a description of a new genus. J. Parasitol., 87, 138-143 (2001).

Chabaud, A.G. and M. Krishnasamy: Noveaux nematodes ugenre Trichospirura Smith et Chitwood, 1967 en Malaysia. Remarques sur l'evolution de la famille des Rhabdochonidae. Ann. Parasitol. Hum. Comp., 50, 813-820(1975). 
David Gonzalez-Solıs, S.P. Chavan, P. Kannewad and G. Gyanath: A new species of Rhabdochona Railliet, 1916 (Nematoda: Rhabdochonidae) from cyprinid fishes in the Western Ghats Region, India. Syst. Parasitol., 87, 273-281 (2014).

Gupta, P.C. and B.A. Masoodi: Three new and one known piscine nematodes from Kanpur. Kanpur Univ. Res. J., 3, 57-70 (1982).

Hamilton, F.: An account of the fishes found in the river Ganges and its branches. Edinburgh, London, pp. 1-405(1822).

Khomdram, B., B. Dhar and S.K. Ghosh: Jiribam, the Ornamental Fishes' Hot Spot Zone of Manipur, India. IOSR-JAVS, 7, 85-91 (2014).

Kottelat, M. and T. Whitten: Freshwater biodiversity in Asia with special reference to fish. World Bank Tech. Paper No. 343, The World Bank, Washington DC, pp. 17-22 (1996).

Moravec, F. and M. Jirku: Rhabdochona spp. (Nematoda: Rhabdochonidae) from fishes in the Central African Republic, including three new species. Folia Parasitol., 61, 157-172 (2014).

Moravec, F. and K. Kamchoo: Description of Rhabdochona (Globochona) rasborae sp. n. (Nematoda: Rhabdochonidae) from the freshwater cyprinid fish Rasbora Paviana Tirant in Southern Thailand. Folia Parasitol., 59, 209-215 (2012).

Moravec, F. and T. Yooyen: Two new species of Rhabdochona (Nematoda: Rhabdochonidae) from freshwater fishes in Thailand. Folia Parasitol., 58, 224-232 (2011).

Moravec, F., G.S. Maldonado and G.C. Carranza: New observations on Vasorhabdochona cablei (Nematoda:Rhabdochonidae) with remarks to the family Rhabdochonidae. Helminthologia, 38, 231235 (2001).

Moravec, F., T. Scholz , A. Ash and P.K. Kar: New data on the morphology and taxonomy of three species of Rhabdochona (Nematoda: Rhabdochonidae) parasitizing fishes in India. Folia Parasitol., 57, 295-306 (2010).

Moravec, F.: General characterization of the nematode genus Rhabdochona with a revision of the South American species. Acta
Soc. Zool. Bohemoslov., 36, 29-46 (1972).

Moravec, F.: Reconstruction of the nematode genus Rhabdochona Railliet, 1916, with a review of the species parasitic in fishes of Europe and Asia. Studie CSVAV, Academia, Prague, 8, 104 (1975).

Moravec, F.: Some aspects of the taxonomy, biology, possible evolution and biogeography of nematodes of the spirurine genus Rhabdochona Railliet, 1916 (Rhabdochonidae, Thelazioidea). Acta Parasitol., 55, 44-160 (2010).

Rai, P.: On some of the hitherto known and unknown nematodes parasitic in some of the freshwater silurid fishes. Indian J. Helminth., 21, 94101 (1969).

Sahay, U. and D. Prasad: On Rhabdochona dasi sp. nov. (Thelaziidae, Rhabdochonidae, Rhabdochona, Railliet, 1916) from a freshwater fish Callichrous pabda (Hamilton). Jap. J. Med. Sci. Biol., 18, 311316 (1965)

Sahay, U. and S. Narayan: A discussion on the validity of Rhabdochona baylisi Rai, 1969. Indian J. Anim. Res., 5, 51-54 (1971).

Sahay, U.: On Rhabdochona bosei sp. nov. from a freshwater fish, Eutropiichthys vacha (Hamilton). Indian J. Helminth., 18, 57-61 (1966).

Saidov, Yu S.: Revision of the family Rhabdochonidae Skrjabin, 1946 and the subfamily Cyclozoninae Sobolev, 1949, Sb. Rabory po gelmintologii Letiyu Akad. K. I. Skrajabina, Moscow, 75, 622-635 (1953).

Soota, T.D.: Studies on nematode parasites of Indian vertebrates. 1. Fishes Rec. Zool. Surv. India, 35, 1-352 (1983).

Vishwanath, W., W. Manojkumar, L. Kosygin and K. S. Selim: Biodiversity of freshwater fishes of Manipur, India. Ital. J. Zool., 65, 321-324 (1998).

Wang, G., Y. Yu and H. Wu: Studies on two new species of Rhabdochona (parasitic nematodes) from Wuling Mountain Region. Acta Hydrobiol. Sin., 18, 280-286 (1994). 